\title{
Assessment of Treatment in Inflammatory Bowel Disease Patients Using Steroid Assessment Tool (SAT) in a Tertiary Center from Romania
}

\author{
Loredana GORAN', Lucian NEGREANU?
}

\begin{abstract}
Background and aims: The evolution of inflammatory bowel diseases was significantly improved during the last decade by the new therapeutic options. Classical medications as corticosteroids and 5-aminosalycilates (5-ASA) are still highly used. In order to evaluate the pattern of corticosteroid usage we used a dedicated online tool-the steroid assessment tool. Our purpose was to evaluate if this tool can permit a change in the therapeutic habits and an improvement of quality of care. We succeeded to outline a therapeutic profile for a series of IBD patients in a tertiary centre from Romania. Methods: Two consecutive assessments were made using an online tool named Steroid Assessment Tool (SAT). Corticosteroid pattern of use and all previous and current treatments were registered and analyzed. Also the epidemiological and clinical data were collected and analyzed. The statistical analysis was performed using SPSS $B$ software. Results: Results showed that most of our IBD patients (90\%) had been treated with 5-ASA, with $29.2 \%$ of CD patients and $54.3 \%$ of UC patients currently using 5-ASA. Also, we had more CD patients (78\%) than UC patients (56.5\%) treated with anti-TNF inhibitors. The rate of thiopurine use was small (2.3\%) and of anti-integrin therapy, interleukin 12/23 inhibitors as well. The rate of corticosteroid use was 34\% in 2019 and in 2020 it dropped to 25\% while the rate of corticosteroid excess was $20.4 \%$ in 2019 with a statistically significant decrease in $2020(p=0,01)$ when it was 5.95\%.Discussion: We managed to draw a therapeutic profile of IBD patients in a tertiary IBD centre from Romania using an online tool named SAT. We noticed that the majority of patients were treated with 5-ASA. Even though 5-ASA are not recommended by recent therapeutic guidelines as treatment for CD, we have $29.2 \%$ of CD patients treated with this class of drugs, a rate smaller than other reports but still outside guidelines. In the same time, we have a higher rate of anti-TNF agents use compared to other studies, but a lower rate of thiopurine use. Corticosteroid use was higher the other reports, but we succeeded to lower the rate of corticosteroid use and the rate of corticosteroid excess.Conclusions: The therapeutic profile and habits of prescription in a tertiary IBD centre were analyzed twice using an easy-to-use online tool. The results obtained in our first evaluation led to a change in the therapeutic management, improving our adherence to guideline's recommendations.
\end{abstract}

Keywords: IBD, 5-ASA, corticosteroid use, corticosteroid excess, SAT.

\section{Rezumat}

Introducere și obiective: Noile opțiuni terapeutice au îmbunătățit evoluția bolilor inflamatorii intestinale, însă corticosteroizii şi 5-aminosalicilații sunt încă foarte utilizați. Utilizând o aplicație online pentru a evalua rata utilizării corticosteroizilor în centrul nostru, am reuşt să schităm un profil terapeutic al pacientilor cu boli inflamatorii intestinale dintr-un centru tertiar din România. Metode: Indicatiile terapeutice si clasele de medicamente utilizate într-un centru terțiar de boli inflamatorii intestinale din România au fost evaluate de două ori utilizând o aplicație online

${ }^{1}$ Department of Internal Medicine I Gastroenterology, Emergency University Hospital, "Carol Davila" University of Medicine and Pharmacy, Bucharest, Romania

\section{Corresponding author:}

Loredana GORAN, Department of Internal Medicine I

Gastroenterology, Emergency University Hospital, „Carol Davila” University of Medicine and Pharmacy, Bucharest, Romania.

E-mail: goran_loredana@yahoo.com 
numită Steroid Assessment Tool. Au fost înregistrate tratamentele anterioare şi cele curente precum şi utilizarea corticosteroizilor, iar datele au fost analizate cu ajutorul programului statistic SPSS $B$. Rezultate: Rezultatele au arătat ca majoritatea (90\%) pacienților noştri au primit tratament cu 5-aminosalicilați, 29,2\% dintre pacienții cu BC şi $54,3 \%$ dintre cei cu RCUH fiind sub tratament curent cu aceasta clasă de medicamente. Am avut mai mulți pacienți cu BC (78\%) decât cu RCUH (56,5\%) tratați cu agenți anti-TNF. Rata utilizării tiopurinelor a fost mică, precum şi a terapiei ant-integrine şi a inhibitorilor interleukinei 12/23. Rata utilizării cosrticosteroizilor a fost de 34\% în anul 2019, scăzând la 25\% în anul 2020, iar rata excesului de cosrticosteroizi a fost de 20,4\% în anul 2019, dar a scăzut semnificativ în anul 2010 ajungând la 5,95\%. Discuții: Am reușit să efectuăm un profil terapeutic al pacienților cu boli inflamatorii intestinale dintr-un centru terțiar din România utilizând o aplicație online - SAT. Am observat că majoritatea pacienților au fost tratați cu 5-aminosallicilați. Deși 5-aminosalicilații nu sunt recomandați în tratamentul bolii Crohn de către ghidurile actuale, 29.2\% dintre pacienții cu BC din centrul nostru sunt au fost tratați cu această clasă de medicamente, un procent mai mic decât cele raportate în alte studii, dar încă în afara recomandărilor ghidurilor de tratament. În același timp avem o rată mai mare de utilizare a agenților anti-TNF comparativ cu alte studii, dar o rată mai mică de utilizare a tiopurinelor. Procentul de utilizare al corticosteroizilor a fost mai mare decât al altor raportări, dar am reușit să reducem utilizarea acestora şi a excesului de corticosteroizi. Concluzii: Profilul terapeutic al pacienților cu boli inflamatorii intestinale dintr-un centru terțiar din România realizat cu ajutorul unei aplicații online a oferit o analiză obiectivă a poziției noastre față de ghidurile de tratament. Rezultatele obținute la prima evaluare au determinat o schimbare a managementului terapeutic al acestor pacienți și a îmbunătățit astfel aderența la ghidurile de tratament.

Cuvinte cheie: boli inflamatorii intestinale, 5-ASA, terapia cu corticosteroizi, exces de cortcosteroizi, SAT.

\section{INTRODUCTION}

Inflammatory bowel diseases (IBD) are chronic diseases of the digestive tract with significant impact on the life quality of patients, but also a burden for healthcare systems through substantial costs associated to treatment of these diseases. New therapeutic options like biologic agents or immunomodulators improved considerably disease evolution for many patients, but corticosteroids and 5-aminosalycilates (5-ASA) are still mainstay treatment options for inducing or maintaining remission of these diseases ${ }^{1}$.

Used since 1955, corticosteroids have confirmed over time their efficiency in controlling IBD symptoms ${ }^{2}$, but the wide range of side effects associated with their use and the lack of efficiency in maintaining disease remission made corticosteroids to be indicated and used strictly for induction of remission ${ }^{3}$.

The complexity of these diseases from diagnosis to treatment and follow-up is probably the reason of the wide national and international variability in managing IBD patients, despite guidelines recommendations. In order to improve quality of care offered to IBD patients, many international organizations developed sets of quality indicators ${ }^{4}$, but for objective evaluation of these indicators there is a need for tools and measurement units so that an accurate assessment lead to a real improvement.
We used an online tool to monitor corticosteroid use in a tertiary IBD centre from Romania and in the same time we managed to draw a therapeutic profile of these patients. The obtained results led to significant changes that improved treatment guidelines adherence and as well quality of care.

\section{METHODS}

\section{Steroid Assessment Tool (SAT)}

An online tool named SAT was developed by AbbVie together with 15 gastroenterologists from the United Kingdom for assessment of corticosteroid use ${ }^{5}$. Patients diagnosed with IBD can be registered alongside with disease severity at the last visit, the current and anterior treatment and the use of corticosteroids in the last 12 months. Regarding treatment it can be registered if the patient is currently or has been previously on treatment with 5-ASA, thiopurines, tumor necrosis factor-alpha inhibitors (anti-TNF), anti-integrin therapy, interleukin 12/23 inhibitors or other immunosuppressants. If the patient has received treatment with corticosteroids in the last 12 months it can also be registered how many courses of steroids he received, the longest period (in months) of steroid use, if he had any criteria of steroid excess as defined by international guidelines ${ }^{3,6}$ and if bone-protection medication was prescribed alongside corticosteroid treatment. 


\section{Study design}

Using SAT, we collected data between January 2019 and March 2020, including patients older than 18 years with a confirmed IBD diagnosis according to international guidelines. A tertiary IBD centre from Romania was evaluated with SAT two times in an interval of 12 months, the first assessment being made in March 2019 on 44 patients and the second one in March 2020 on 84 patients. The statistical analyze was made using SPSS $^{\circledR} 7$ software.

\section{Steroid excess}

The inability to reduce the doses of steroids below the equivalent of $10 \mathrm{mg} /$ day of prednisolone or $3 \mathrm{mg} /$ day of budesonide within 3 months of starting the treatment without signs of recurrent disease or a disease relapse within 3 months from discontinuing the steroid treatment or the need for more than one course of steroids per year defines steroid excess ${ }^{3,6}$. In order to determine if there is any statistically significant difference between the expected and the observed frequencies, we used the Chi-squared test with a level of significance of $\mathrm{p}=0.05$.

\section{RESULTS}

The study included a total of 128 IBD patients, 44 of them being evaluated with SAT in March 2019 and 84 patients in March 2020.

Distribution of patients according to disease type revealed that 82 patients (64\%) had Crohn's disease (CD) and 46 patients (36\%) had ulcerative colitis (UC), with a mean age of 39 years $( \pm 13.02)$ and a predominance of male gender (69\% males, 31\% females). Regarding disease severity at the last evaluation, $63 \%$ of patients (81 patients) were considered to be in remission, $31 \%$ patients (40 patients) had moderate disease and $5.4 \%$ patients ( 7 patients) had severe disease. There were $57 \mathrm{CD}(70.4 \%)$ patients and $24 \mathrm{UC}$ patients $(29.6 \%)$ with mild course of disease, while there were $2.4 \% \mathrm{CD}$ patients and $10 \%$ UC patients with severe course of disease.

Using SAT, we noticed that 115 patients (90\%) from the total of 128 patients were treated or are currently under treatment with 5-ASA, while 13 patients (10\%) had never been treated with 5-ASA. From the 115 patients treated with 5-ASA, 66 patients (57\%) followed a treatment with 5-ASA before the SAT evaluation and 49 patients (43\%) were currently using 5-ASA when SAT assessment was made (Figure 1).

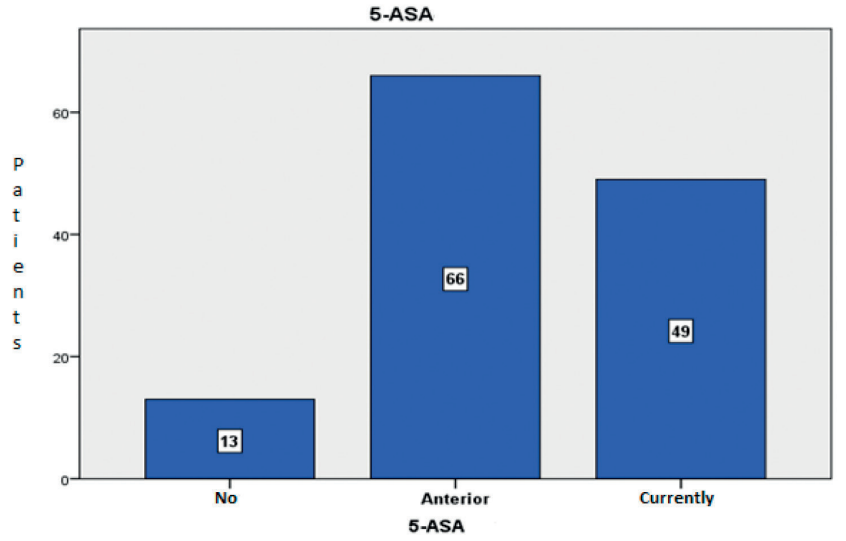

Figure 1. Distribution of 5-ASA administration in IBD patients

Regarding 5-ASA use depending on disease type we observed that $69 \mathrm{CD}$ patients $(84 \%)$ from the total of $82 \mathrm{CD}$ patients received a prescription of 5-ASA, while all UC patients (100\%) followed a 5-ASA based treatment. Thus, as more UC patients were treated with 5-ASA than CD patients, we found a weak but statistically significant differentiation between the CD group (69 patients, 84\%) and the UC group (46 patients, $100 \%)$ depending on 5-ASA utilization $\left(\mathrm{X}^{2}=\right.$ 8.11, $\mathrm{p}=0.004$, Cramer's V=0.25).

The study included $82 \mathrm{CD}$ patients from which 24 patients (29.2\%) were currently using 5-ASA when the SAT evaluations were made, while 45 patients (54\%) used 5-ASA before the evaluation and 13 patients (15.8\%) had never used 5-ASA. In the UC group that included 46 patients, 25 patients (54.3\%) were currently treated with 5-ASA at the moment of SAT evaluation and 21 patients (45.6\%) were treated with 5-ASA before the evaluation (Figure 2).

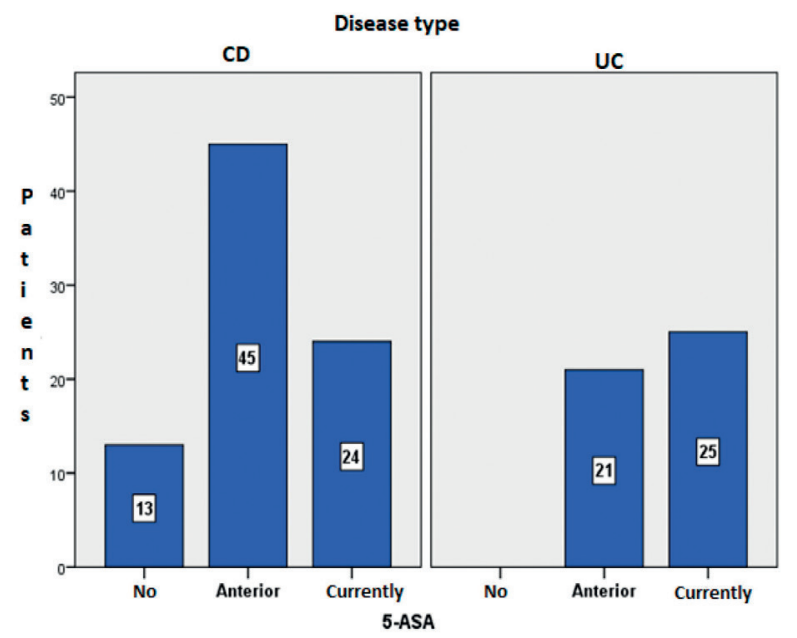

Figure 2. Distribution of 5-ASA administration depending on disease type 
Regarding anti-TNF treatment, we noticed that 85 patients $(66.4 \%)$ were treated with anti-TNF agents, while 43 patients $(33.5 \%)$ had never been treatment with anti-TNF inhibitors. Most of the patients $(72$ patients, 85\%) were currently treated with ani-TNF agents at the moment of SAT evaluation and 13 patients $(15 \%)$ had an anti-TNF based treatment before the evaluations (Figure 3).

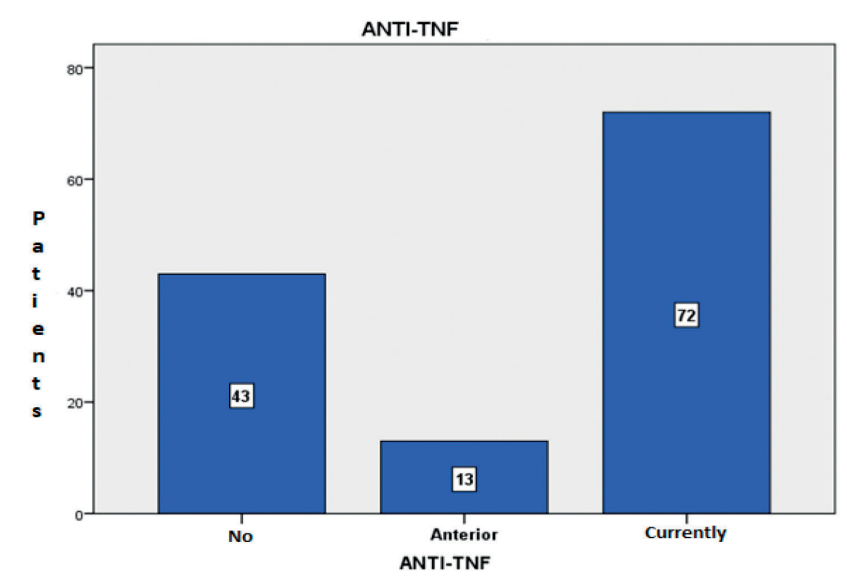

Figure 3. Distribution of anti-TNF treatment in IBD patients

Distribution of anti-TNF treatment depending on disease type showed that $59 \mathrm{CD}$ patients (78\%) out of 82 patients and $26 \mathrm{UC}$ patients $(56.5 \%)$ out of 46 patients were treated with anti-TNF inhibitors (Figure 4). As more CD patients than UC patients were treated with ani-TNF medication, we found a weak but statistically significant differentiation between the CD and UC patient group depending on administration of anti-TNF agents $\left(X^{2}=3.14, p=0,05\right.$, Cramer's $\left.V=0.15\right)$.

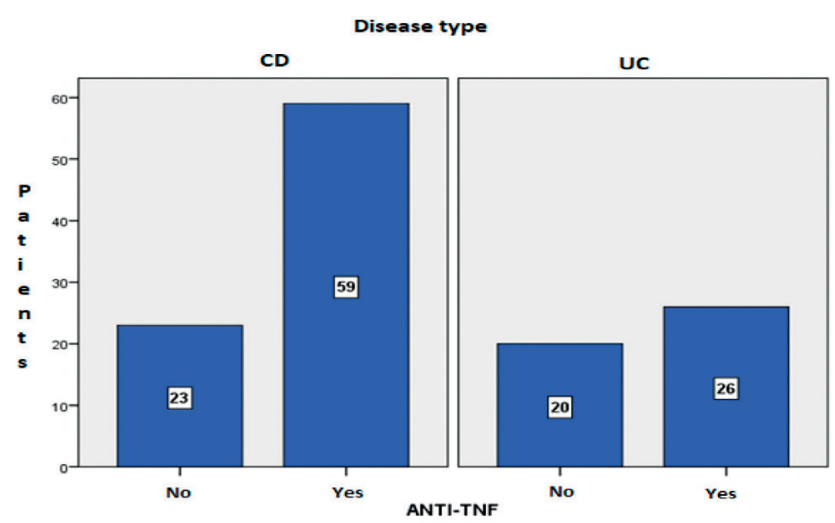

Figure 4. Distribution of anti-TNF treatment depending on disease type
Only 15 patients $(11.7 \%)$ of the total of 128 IBD patients were treated with thiopurines, 3 patients $(2.3 \%)$ being currently under thiopurine treatment at the moment of SAT evaluation and 12 patients (9.3\%) had been treated with this class of medication before the evaluation (Figure 5). Distribution of thiopurine therapy depending on disease type revealed that $10 \mathrm{pa}-$ tients out of the total of 15 patients treated with thiopurines were $\mathrm{CD}$ patients and 5 patients were UC patients.

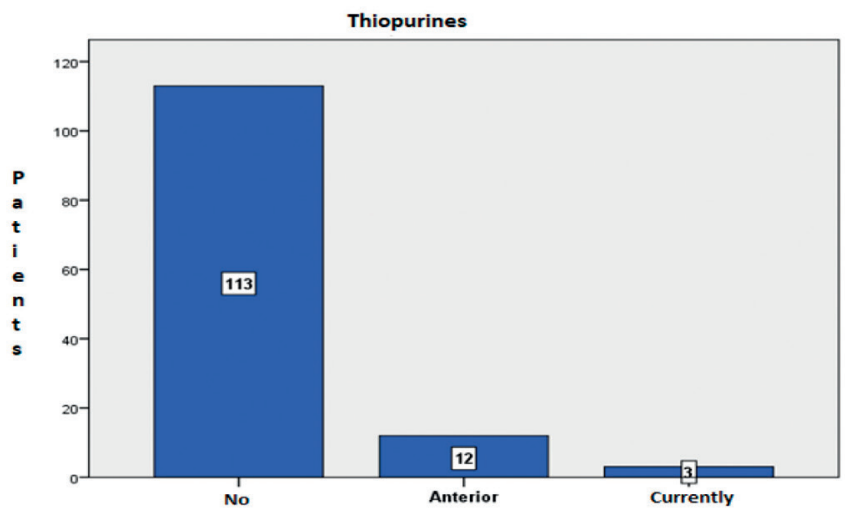

Figure 5. Distribution of thiopurine treatment in IBD patients

Anti-integrin therapy was used in 5 patients (3.9\%), while the rest of 123 patients (96\%) were never treated with anti-integrin therapy. Interleukin 12/23 inhibitors were used in 2 patients (1.5\%) and 7 patients (5.4\%) were treated with other immunosuppressants.

Treatment with corticosteroids was administered to 15 patients (34\%) out of 44 patients in 2019, while in 2020 it was prescribed to 21 patients $(25 \%)$ of the total of 84 patients (Figure 6), a decrease that did not reach statistical significance $\left(\mathrm{X}^{2}=1.18, \mathrm{p}=0.27\right)$.

The rate of corticosteroid excess as define by international guidelines was $20.4 \%$ in 2019 and fell to $5.95 \%$ in 2020 , a decrease that was statistically significant $\left(\mathrm{X}^{2}=6.23, \mathrm{p}=0.01\right.$, Cramer's $\left.\mathrm{V}=0.22\right)$. 


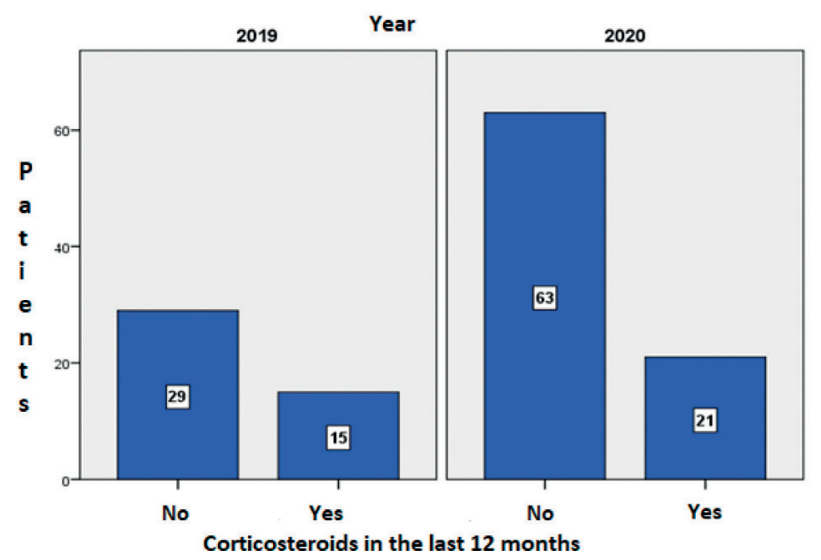

Figure 6. Corticosteroid use in 2019 and 2020

\section{DISCUSSIONS}

A tertiary IBD centre from Romania was evaluated using an online tool - SAT at an interval of one year, the first evaluation being made in March 2019 on 44 IBD patients and the second one in March 2020 on 84 IBD patients. Thus, the study included 128 IBD patients, most of them being $\mathrm{CD}$ patients $(64 \%, 82$ patients) while the rest of them were UC patients $\left(36 \%, 46 \mathrm{pa}^{-}\right.$ tients), with a predominance of male gender $(68 \%)$ and a mean age of 39 years.

SAT evaluation revealed that a considerable number of patients $(90 \%, 115$ patients) received a treatment with 5-ASA before the evaluation or were currently under treatment at the moment of the evaluation. The percent of the patients currently treated with 5-ASA at the moment of SAT evaluation is $43 \%$ (49 patients), while 57\% (66 patients) were treated with 5-ASA before the SAT assessment. Distribution of 5-ASA administration depending on disease type showed that all UC patients (100\%) were treated with 5-ASA at one moment in their evolution, while $84 \%$ of $\mathrm{CD}$ patients (69 patients) received a 5-ASA based treatment. We found a weak but statistically significant differentiation between the UC and CD patients, as more UC patients than $\mathrm{CD}$ patients were treated with 5-ASA ( $\mathrm{p}=$ 0,004). Similar results were found in other studies too, with more UC patients than $\mathrm{CD}$ patients treated with 5-ASA ${ }^{8}$.

A significant number of $\mathrm{CD}$ patients with colonic and ileo-colonic lesions were treated over time with 5-ASA 9 , but recent treatment guidelines do not recommend the use of 5-ASA in CD patients as many studies reported a lack of efficiency of 5-ASA in treatment of $\mathrm{CD}^{3}$. In Europe, 5-ASA are commonly used in $\mathrm{CD}$ patients despite evidence regarding the lack of efficiency of 5-ASA in CD ${ }^{10}$. It was observed that for $\mathrm{CD}$ there was a decrease in 5-ASA prescriptions between 1990 and 2010, but 56,4\% of CD patients were still treated with 5-ASA between 2006 and 2010, while $49 \%$ of UC patients were on prolonged use of 5 -ASA ${ }^{11}$.

In our study, $45 \mathrm{CD}$ patients out of $69 \mathrm{CD}$ patients were treated with 5-ASA before the SAT evaluation, thereby our rate of current 5-ASA utilization in CD patients is $29.2 \%$, a rate smaller than those obtained in other studies where $62.3 \% \mathrm{CD}$ patients were treated with 5-ASA ${ }^{8}$. In a study from the United Kingdom made between 2006-2018 on CD patients, it was observed that $44 \%$ of these patients received a 5 -ASA prescription, the majority being treated with oral 5-ASA as monotherapy, with 25,3\% still being treated with 5 -ASA at 10 years ${ }^{12}$.

An important number of IBD patients from our study $(66.4 \%, 85$ patients) received a treatment based on anti-TNF agents, most of them (85\%, 72 patients) being on this treatment when SAT evaluations were made. We had more CD patients (78\%, 59 patients) than UC patients $(56.5 \%, 26$ patients) treated with anti-TNF inhibitors, a weak but statistically significant differentiation $(\mathrm{P}=0,05)$. We have a higher utilization rate of anti-TNF inhibitors compared to other studies where the reported rates are $23.9 \%{ }^{13}$ and $28.5 \%{ }^{8}$.

It was observed that $10-30 \%$ of IBD patients do not respond to biologic agents and 20-50\% of those who primary have a response to treatment develop treatment resistance in the first year ${ }^{14}$. In our study a number of 13 IBD patients (15\%) were treated with anti-TNF agents before the SAT evaluation and their treatment was stopped due to a primary non-response, or due to treatment resistance.

While we have a high utilization rate of anti-TNF agents, we have a smaller rate of thiopurine use of only $11.7 \%$ (15 patients) as compared to other studies where the reported rates are $62.6 \%{ }^{8}$. Over time it was noticed a trend of an increase in thiopurines prescription in CD patients from $14 \%$ between 1990-1993 to $47.1 \%$ between 2006-2010 together with a decrease in steroid dependency ${ }^{11}$. Our rate of thiopurine use is comparable to the one reported 30 years ago in the previous mentioned study. In UC patients from Japan it was noticed a increase of thiopurine and biologic prescriptions, as well as a decrease in corticosteroid use ${ }^{15}$. 
The rate of anti-integrin therapy use in our study was 3.9\% (5 patients), a value higher than the one reported in a study from the United Kingdom ${ }^{8}$ but we have to mention that the number of patients included in our study is smaller than the number in the afore mentioned study. The use of interleukin 12/23 inhibitors is also small, only 2 patients $(1.5 \%)$ being treated with this class of medication.

Regarding corticosteroid use we obtained a rate of 34\% in 2019 after the first SAT evaluation, a value higher than other reports where the rate of corticosteroid use was $30 \%{ }^{8}$ in the United Kingdom and 26.3\% ${ }^{16}$ in Asia. We managed to obtain a decrease in 2020 when the rate of corticosteroid use was $25 \%$, but the decrease was not statistically significant compared to other studies ${ }^{13}$. The rate of steroid excess was evaluated by SAT to be $20.4 \%$ in 2019 , similar to reports from Kent ${ }^{17}$ and we succeeded to obtain a statistically significant decrease $(p=0.01)$ in 2020 when the rate of steroid excess dropped to $6 \%$.

Distribution of patients depending on disease severity showed that most of the cases $(63 \%)$ were evaluated as being in remission, $31 \%$ were moderate cases and $5.4 \%$ were considered severe cases. We noticed that there were more $\mathrm{CD}(70.4 \%)$ than UC patients $(29.6 \%)$ with mild courses of disease $(p=0,05)$. At the same time, there were more UC patients $(10 \%)$ than
CD patients $(2.4 \%)$ with severe courses of disease $(p=0,04)$. We consider that the increased number of $\mathrm{CD}$ patients with mild course of disease is related to the fact that more $\mathrm{CD}$ patients are treated with biologic agents.

\section{CONCLUSION}

We managed to draw a therapeutic profile of IBD patients in a tertiary IBD centre from Romania using an online tool named SAT. We observed that even if 5-ASA utilization in CD patients is decreasing we are still outside guideline recommendations. Also, we have a high rate of anti-TNF agents use compared to other international centres, but a low rate of immunomodulators use. The rates of corticosteroid use, and steroid excess were high in 2019 compared to other reports but we managed to reduce them, especially the steroid excess rate that was reduced significantly.

\section{Compliance with ethics requirements:}

The authors declare no conflict of interest regarding this article. The authors declare that all the procedures and experiments of this study respect the ethical standards in the Helsinki Declaration of 1975, as revised in 2008(5), as well as the national law. Informed consent was obtained from all the patients included in the study. 


\section{References}

1. Neurath MF. Current and emerging therapeutic targets for IBD. Nature Reviews Gastroenterology and Hepatology. 2017.

2. Truelove SC. Cortisone in Ulcerative Colitis Final Report on a Therapeutic Trial. Br Med J. 1955;

3. Torres J, Bonovas S, Doherty G, Kucharzik T, Gisbert JP, Raine T, et al. ECCO Guidelines on Therapeutics in Crohn's Disease: Medical Treatment. J Crohns Colitis. 2020;

4. Fiorino G, Lytras T, Younge L, Fidalgo C, Coenen S, Chaparro M, et al. Quality of care standards in inflammatory bowel diseases: a European Crohn's and Colitis Organisation (ECCO) position paper. J Crohn's Colitis. 2020;

5. https://www.steroidassessmenttool.com/.

6. Harbord M, Eliakim R, Bettenworth D, Karmiris K, Katsanos K, Kopylov U, et al. Third European evidence-based consensus on diagnosis and management of ulcerative colitis. Part 2: Current management. J Crohn's Colitis. 2017;11(7):769-84.

7. SPSS [Internet]. Available from: https://www.ibm.com/analytics/spss-statistics-software

8. Selinger CP, Parkes GC, Bassi A, Fogden E, Hayee B, Limdi JK, et al. A multi-centre audit of excess steroid use in 1176 patients with inflammatory bowel disease. Aliment Pharmacol Ther. 2017;

9. Gearry RB, Ajlouni Y, Nandurkar S, Iser JH, Gibson PR. 5-Aminosalicylic acid (Mesalazine) use in Crohn's disease: A survey of the opinions and practice of Australian gastroenterologists. Inflamm Bowel Dis. 2007;

10. Burisch J, Bergemalm D, Halfvarson J, Domislovic V, Krznaric Z, Goldis A, et al. The use of 5 -aminosalicylate for patients with Crohn's disease in a prospective European inception cohort with 5 years follow-up - an Epi-IBD study. United Eur Gastroenterol J. 2020;
11. Chhaya V, Saxena S, Cecil E, Subramanian V, Curcin V, Majeed A, et al. Steroid dependency and trends in prescribing for inflammatory bowel disease - a 20-year national population-based study. Aliment Pharmacol Ther. 2016;

12. Hart A, Ng SC, Watkins J, Paridaens K, Edwards JO, Fullarton JR, et al. The use of 5-aminosalicylates in crohn's disease: A retrospective study using the uk clinical practice research datalink. Ann Gastroenterol. 2020;

13. Selinger CP, Parkes GC, Bassi A, Limdi JK, Ludlow H, Patel P, et al. Assessment of steroid use as a key performance indicator in inflammatory bowel disease-analysis of data from 2385 UK patients. Aliment Pharmacol Ther. 2019;

14. Kim KU, Kim J, Kim WH, Min H, Choi CH. Treatments of inflammatory bowel disease toward personalized medicine. Archives of Pharmacal Research. 2021.

15. Matsuoka K, Igarashi A, Sato N, Isono Y, Gouda M, Iwasaki K, et al. Trends in Corticosteroid Prescriptions for Ulcerative Colitis and Factors Associated with Long-Term Corticosteroid Use: Analysis Using Japanese Claims Data from 2006 to 2016. J Crohns Colitis. 2021;

16. Kim DH, Park DI, Kobayashi T, Ahuja V, Jang BI, Cao Q, et al. P691 Corticosteroids usage in patients with inflammatory bowel disease: Results of a multi-national audit in Asia. J Crohn's Colitis. 2020;

17. Scott G, Roads N, Lewis W. P280 Reducing the overprescribing of oral corticosteroids in IBD using a steroid assessment tool. J Crohn's Colitis. 2018;12(supplement_1):S242-S242. 